\title{
Factor structure of the comprehensive preparedness of shooters 14-15 years old, specializing in shooting from classic bow
}

\author{
Sobko I.M. ${ }^{1}$, Kovtun A.L. ${ }^{1}$, Ulaeva L.O. ${ }^{2}$ \\ ${ }^{1}$ H.S. Skovoroda Kharkiv National Pedagogical University \\ ${ }^{2}$ National university of pharmacy
}

\section{DOI: https://doi.org/10.34142/HSR.2019.05.01.11}

\section{Abstract}

The purpose of the work: to determine the factor structure of the complex preparedness of shooters of 14-15 years who specialize in the Classic bow, for rational construction of the training process of athletes of this age category.

Material and methods. The experiment was attended by 16 bow-shooters (girls) aged 14-15 years old, specializing in Classic bow, sport school "Avangard" in Kyiv. The experiment was conducted in the preparatory period, September 2018. The archers were tested for physical fitness (shuttle running 4x9m, push-ups $30 \mathrm{~s}$, jumping with skipping-rope, running $30 \mathrm{~m}$, Romberg test, hanging on bent hands at an angle of $90^{\circ}$, jump in length from place, raising the torso to a sitting position, dynamometry of the right and left hands), technical preparedness (holding the bow in the "stretch", archery $18 \mathrm{~m}$, archery $60 \mathrm{~m}$, stretching the bow on the right and left hand for $30 \mathrm{~s}$ ). The obtained data were processed mathematically using factor analysis methods.

Results. The factor structure of physical and technical preparedness of shooters, which are at the stage of specialized basic training, is established. Five factors were identified: static power endurance, dynamic power endurance, coordination capabilities, speed capabilities, strength capabilities.

Conclusions. It is revealed that the most important indicators of the complex training of archers 14-15 years old are the indicators of shooting in the open air and indicators of the static strength of the archer, as well as indicators of shooting in the room and indicators of the dynamic endurance of the archer, indicating the dependence of physical and technical training. The use of rational means and methods of physical and technical training in the training process of athletes is recommended.

Key words: archery; shooters; factor analysis; technical preparedness; physical preparedness.

\section{Анотація}

Собко И.М., Ковтун А.Л., Улаєва Л.О. Факторна структура комплексної підготовленості стрільців 14-15 років, що спеціалізуються в стрільбі з класичного луку

Мета роботи: визначення факторної структури комплексної підготовленості стрільців 14-15 років, що спеціалізуються в стрільбі з олімпійського лука, для раціональної побудови тренувального процесу спортсменів цієї вікової категорії.

Матеріал і методи. В експерименті взяли участь 16 стрільців (дівчат) у віці 14-15 років, що спеціалізуються в стрільбі $з$ олімпійського лука, які займаються в ДЮСШ «Авангард» в м. Києві. Експеримент проводився в підготовчому періоді, вересень 2018 року. Лучники пройшли тестування фізичної підготовленості (човниковий біг 4х9 м, згинання, розгинання рук в упорі лежачи за 30 с, стрибки зі скакалкою, біг 30 м, проба Ромберга, вис на зігнутих руках під кутом 90, стрибок в довжину з місця, підняття түлуба в сід, динамометрія правої і лівої рук), технічна підготовленість (үтримання лука в «розтягу», стрільба з лука 18 м, стрільба з лука 60 м, розтягнення лука правою і лівою рукою протягом 30 с). Отримані дані були оброблені математично 3 використанням методів факторного аналізу.

Результати. Встановлена факторна структура фізичної та технічної підготовленості лучників, які перебувають на етапі спеціалізованої базової підготовки. Були визначені п'ять факторів: статична витривалість, динамічна витривалість, координаційні здібності, швидкісні здібності, силові здібності.

Висновки. Виявлено, що найбільш важливими показниками комплексної підготовки лучників 14-15 років, $є$ показники стрільби на відкритому повітрі і показники прояву статичної сили лучника, а також показники стрільби в приміщенні і показники прояву динамічної витривалості лучника, що вказують на залежність фізичної та технічної підготовки. Рекомендовано використання раціональних засобів і методів фізичної і технічної підготовки в тренувальному процесі спортсменів. Ключові слова: стрільба з лука; лучники; факторний аналіз; технічна підготовка; фізична підготовка.

\section{Аннотация}

Собко И.Н., Ковтун А.Л., Улаева Л.А. Факторная структура комплексной подготовленности стрелков 14-15 лет, специализирующихся в стрельбе из классического лука

Цель работы: определение факторной структуры комплексной подготовленности стрелков 14-15 лет, специализирующихся в стрельбе из олимпийского лука, для рационального построения тренировочного процесса спортсменов этой возрастной категории.

Материал и методы. В эксперименте приняли участие 16 стрелков (девочек) в возрасте 14-15 лет, специализирующихся в стрельбе из олимпийского лука, которые занимаются в ДЮСШ «Авангард» в м. Киеве. Эксперимент проводился в подготовительном периоде, сентябрь 2018 года. Лучники прошли тестирование физической подготовленности (челночный бег 4х9 м, згибание, разгибание рук в упоре лежа за 30 с, прыжки со скакалкой, бег 30 м, проба Ромберга, вис на согнутых руках под углом 90, прыжок в длину с места, поднятие туловища в сед, динамометрия правой и левой рук), техническая подготовленность (удержание лука в «растяжке», стрельба из лука 18 м, стрельба из лука 60 м, растяжение лука правой и левой рукой в течение 30 с). Полученные данные были обработаны математически с использованием методов факторного анализа. Результаты. Определена факторная структура физической и технической подготовленности лучников, находящихся на этапе специализированной базовой подготовки. Были определены пять факторов: статическая выносливость, динамическая выносливость, координационные способности, скоростные способности, силовые способности.

Выводы. Выявлено, что наиболее важными показателями комплексной подготовки лучников 14-15 лет, являются показатели стрельбы на открытом воздухе и показатели проявления статической силы лучника, а также показатели стрельбы в помещении и показатели проявления динамической выносливости лучника, указывающие на зависимость физической и технической подготовки. Рекомендовано использование рациональных средств и методов физической и технической подготовки в тренировочном процессе спортсменов.

Ключевые слова: стрельба из лука; лучники; факторный анализ; техническая подготовка; физическая подготовка 


\section{Introduction}

The problem of training athletes in Olympic sports is highly relevant $[1,2]$. Qualitative improvement of sports and technical skills is the main task in the preparation of archers. Modern archery is a complex technical sport that places great demands on the physical, technical, tactical and psychological training of athletes of various qualifications. However, for beginners, archers is an interesting and accessible sport due to its emotional appeal and low energy costs. The practice of sports work and the results of scientific research show that systematic training for 8-10 years is necessary to achieve international class results in shooting sports [3]. In this regard, at each stage of multi-year preparation, it is necessary to search for the most effective ratios of loads of various directions and new forms of organization of the training process.

A theoretical analysis of scientific and methodical studies in archery indicates existing scientific data on improving the effectiveness of training with the help of control exercises with complicated performance conditions (shooting sitting on a chair, standing on the platform, eyes closed) [3], using a balance board with additional optical gun and special target exercises [4], as well as by improving the technical means of teaching motor actions [2].

Modern scientific research is devoted to the content of sports training of archers are focused mainly on the training of qualified athletes [5, 6]. Scientists have found that the sporting success of highly skilled shooters is most determined by the coordination abilities of the athlete. The stability of the shooter-weapon system largely depends on the ability to control this system when exposed to external and internal factors: the speed at which the shot is executed, the content front sight during aiming, and the processing of the shot [2,7]. Some scientists note the importance of the problem of psycho-emotional stability of the shooter, which is essentially expressed in the duration of the retention of the sight at the center of the target until it stops completely [8]. Tarasova et.al. [7] determined the factor structure of the functional state and special physical performance of skilled archery shooters, which allowed to identify the most significant factors. Studies to determine the biomechanical and physiological parameters of archery are conducted by many researchers [9-11]. Some experts compared the muscular activity of the shoulder girdle and upper extremity of athletes with different levels of experience in archery and determined that training lower trapezius muscles actively influences the improvement of archery skills [12].
In methodical and partially in scientific studies it has been shown that effective work with young athletes is possible only on the basis of taking into account physiological changes that occur in the body of adolescents [13, 14]. Moreover, since the age of 10-15 is most favorable for the development of special physical qualities and the formation of specific coordination abilities. At the initial basic specialization stage, special attention is recommended to be paid to the development and improvement of the special quality of the archer differentiation of the speed at which the boom reaches down. At the stage of special basic training, the training process is aimed at the development and improvement of special physical and technical training of athletes in accordance with the requirements of the specifics of archery. During this period, athletes begin to actively participate in competitions in the categories of Olympic and block bow. Therefore, when selecting training bows, coaches need to take into account the differences between Olympic and block bows. The main difference lies in the presence of a block system located on his shoulders, therefore the speed of the arrow and the strength of the shot of such a bow exceeds any Olympic variant by half or even three times. In contrast to the classic, a shot in a block bow occurs not only due to the strength of the shoulders, but also through the use of a system of block mechanisms.

In connection with the characteristics of the competitive activity of archers, and their specialization, the importance of physical and technical readiness in the formation and improvement of sportsmanship of athletes increases.

Thus, the purpose of our study was to determine the factor structure of the complex preparedness of shooters 14-15 years old, specializing in Classic bow, for the rational construction of the training process of athletes of this age category.

\section{Material and methods}

\section{Participants}

The experiment was attended by 16 bowshooters (girls) aged 14-15 years old, specializing in Classic bow, Athletes have three years of experience in archery and are part of a group of basic training, sport school "Avangard" in Kyiv. The experiment was conducted in the preparatory period, September 2018 .

Methods

- To determine the level of development of physical fitness, the following tests were used: 
- Shuttle run $4 \times 9 \mathrm{~m}$ was performed with a stop and touching the line. The execution time was fixed (s).

- Push-ups 30 s (number of times).

- Jumps with skipping-rope, (number of times).

- Running 30 m (s).

- Romberg's test (s)

- Hang on bent arms at an angle of $90^{\circ}$ (s).

- Long jump from the spot $(\mathrm{cm})$.

- Raising the torso to a sitting position (number of times).

- Dynamometer of the right and left hand $(\mathrm{kg})$.

To determine the level of technical development of basketball players, the following tests were used:

- Bow content in "stretching". Testing was performed standing, the execution time (s) was recorded.

- Stretching a bow with right and left hand for $30 \mathrm{~s}$. Testing was performed standing, recorded a number of times.

- Archery $18 \mathrm{~m}$ (number of points). Shooting is performed indoors at a distance of 18 meters at the target (120 s per series). There are a total of 20 series of 3 arrows each. Fixed number of points.
- Archery $60 \mathrm{~m}$ (number of points). Shooting is done in the air at a distance of 60 meters at the target ( 240 seconds per series). There are a total of 12 series of 6 arrows each. Fixed number of points.

\section{Statistical analysis}

Digital material was processed using traditional methods of mathematical statistics using Microsoft Excel, SPSS. The factor analysis was used by the method of main components to determine the hidden relationships between the indicators of special physical and technical readiness of athletes. The analysis served as a means of reducing variables and identifying the main components that determine the structure of the complex preparedness of athletes.

\section{Results}

Conducting a factor analysis, with the help of which a large number of variables (in our case, 15), was reduced to a smaller number of independent values, allowed us to identify five factors (Table 1).

Matrix of components in factor analysis of indicators of complex testing of bow arrows $(n=16)$

\begin{tabular}{|c|c|c|c|c|c|c|}
\hline \multirow{2}{*}{ The name of the factor } & \multirow{2}{*}{ Indication } & \multicolumn{5}{|c|}{ Factors } \\
\hline & & 1 & 2 & 3 & 4 & 5 \\
\hline \multirow{6}{*}{ Static power endurance } & Archery $60 \mathrm{~m}$, number of points & 0,697 & & & & \\
\hline & Push-ups $30 \mathrm{~s}$, number of times & 0,674 & & & & \\
\hline & Bow content in "stretching", s & 0,621 & & & & \\
\hline & Romberg's test, s & 0,592 & & & & \\
\hline & Hang on bent arms at an angle of $90^{\circ}, \mathrm{s}$ & 0,565 & & & & \\
\hline & Long jump from the spot, $\mathrm{cm}$ & 0,563 & & & & \\
\hline \multirow{4}{*}{$\begin{array}{l}\text { Dynamic power } \\
\text { endurance }\end{array}$} & Archery $18 \mathrm{~m}$, number of points & & $-0,810$ & & & \\
\hline & $\begin{array}{c}\text { Stretching a bow with left hand for } 30 \mathrm{~s} \text {, } \\
\text { number of times }\end{array}$ & & 0,682 & & & \\
\hline & $\begin{array}{c}\text { Stretching a bow with right hand for } 30 \mathrm{~s} \text {, } \\
\text { number of times }\end{array}$ & & 0,564 & & & \\
\hline & $\begin{array}{c}\text { Raising the torso to a sitting position, number } \\
\text { of times }\end{array}$ & & $-0,587$ & & & \\
\hline \multirow{3}{*}{ Coordination capabilities } & Jumps with skipping-rope, number of times & & & 0,569 & & \\
\hline & Shuttle run $4 \times 9 \mathrm{~m}, \mathrm{~s}$ & & & 0,715 & & \\
\hline & Dynamometer of the left hand, $\mathrm{kg}$ & & & 0,647 & & \\
\hline Speed capabilities & Running $30 \mathrm{~m}, \mathrm{~s}$ & & & & 0,706 & \\
\hline Power capabilities & Dynamometer of the right hand, $\mathrm{kg}$ & & & & & 0,486 \\
\hline
\end{tabular}

The first factor was called "Static power endurance". It includes test indicators: hanging on bent arms at an angle of $90^{\circ}(\mathrm{r}=0.56)$, Romberg's test $(r=0.59)$, bow content in "stretching" $(r=0.62)$. These indicators characterize the endurance to longterm work of moderate power, the steady content of the stretched bow in the process of aiming and processing the release of the boom, including the functioning of the majority of the muscular system. This factor also includes indicators of testing flexion, push-ups $30 \mathrm{~s},(\mathrm{r}=0.67)$ and a long jump from the spot $(r=0.56)$. These indicators characterize the 
power capabilities of archers related to keeping the bow in a static position, the ability to maintain optimal power stresses for a long time. All indicators form the highest correlation coefficients with the first indicator of archery testing $60 \mathrm{~m}(\mathrm{r}=0.69)$. After all, the manifestation of the static power endurance of an archer is the ability to maintain an optimal level of performance during the entire shooting exercise for a few hours both during the competition and during training.

The second factor included the indicators that form the highest correlation coefficients with the first indicator of this factor archery $18 \mathrm{~m}(\mathrm{r}=0.81)$. These are indicators of stretching the bow with right and left hands for $30 \mathrm{~s}(\mathrm{r}=0.68-0.54)$ and raising the torso to a sitting position $(\mathrm{r}=-0.516)$. These indicators characterize the archers' ability to work for a long time and efficiently, aimed at multiple bow tension, therefore the second factor was named "Dynamic power endurance".

The third most important factor was named "Coordination capabilities". It included such indicators as jumping skipping-rope for $1 \mathrm{~min}(\mathrm{r}=$ $0.56)$, shuttle running $4 \times 9 \mathrm{~m}(\mathrm{r}=0.71)$, dynamometer of the left hand $(r=0,64)$. This factor is not less significant, because a high level of coordination abilities allows you to quickly acquire new motor skills; rationally carry out the existing stock of skills, abilities and motor skills; show the necessary variation of movements in accordance with the specific situations of training and competitive activities. In archery, coordination abilities are largely due to the speediness of the athlete, which is necessary for processing information received from visual, kinesthetic, tactile, auditory analyzers. This suggests that the improvement of technical skill is carried out through the improvement of the properties of analyzers, provide rich information about the nature and degree of accuracy of the actions performed in specific conditions and improve consistency in their work.

The fourth factor and the fifth factor included the test running $30 \mathrm{~m}(\mathrm{r}=0.821)$ and dynamometry of the right hand $(r=0.48)$, they were called "Speed capabilities" and "Power capabilities", respectively. These indicators stood out in separate factors, as the speed capabilities of the shooters provide a quick rise of the bow and its stretching when firing in adverse meteorological conditions and with a shortage of time left to execute the shot. And power capabilities are manifested in opposition to the growing fatigue caused by the power component of the load, that is, the onion content in a relatively stable position (a certain time) and its tension.

Thus, in the general structure of preparedness of archers, five factors were singled out, the percentage of which from the total variance is presented in Fig. 1.

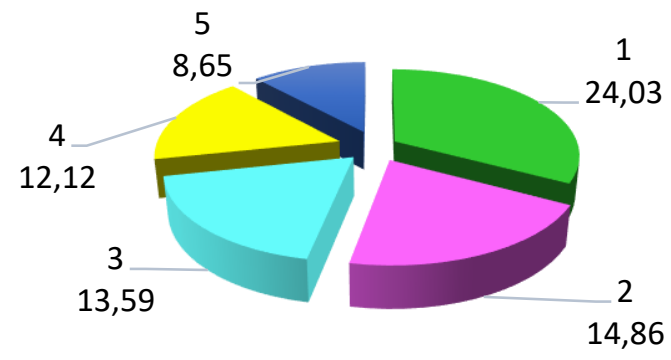

Fig. 1. The percentage of the total variance of the main factors of testing Archers

Analyzing the percentage contribution of various factors to the total variance, we note that the first factor "Static power endurance" prevails in the structure of preparedness of shooters from the bow. Then follow the second and third factors, their percentage contribution is almost the same, which indicates the equal importance of these factors. This can be explained by the fact that the activity of the shooter, who specializes in the Classic bow, is the alternation of long-term static and dynamic relatively uniform work performed in a few hours. But the amount of static work is much higher, since with static voltage fatigue occurs faster than with dynamic. This is due to the large load on the nervous system, which should regulate the high accuracy and uniformity of muscular effort with a large number of executed shots. Coordination capabilities depend on the archer's motor fitness, as well as on the effectiveness of mental processes that determine the reliability of motion control and ensure that the athlete performs technical actions at the same time. Coordination abilities are needed to execute the shot, ensure the sustainability of the "gunner-weapon" system and adequately respond to changes in the conditions of sports activity (lighting, wind, rain, etc.).

\section{Discussion}

Modern scientists [15-17] actively apply multivariate analysis methods to study the structure of the integrated fitness of young and skilled athletes 
in various sports. Leading Ukrainian specialists [18] consider factor analysis to be the most appropriate mathematical tool. It allows you to reduce a wide range of indicators of preparedness and to identify the main components that determine the exact characteristics of the individual characteristics of athletes. The use of modern methods of analysis helps to create optimal training methods that best meet the requirements of the training process in a specific period of time. In sports games, using factor analysis, scientists [19] develop individual factor models of physical fitness of athletes of various game roles. In this regard, the studies conducted in this work confirm and supplement the data of the listed authors about the need to use a wide range of physical and technical readiness indicators to determine the factor structure of preparedness of archery shooters aged $14-15$ years.

Sport experts emphasize that sporting achievements in archery are determined by the level of technical readiness of an athlete, because the strength of the shooter is characterized by the degree of quality of the motor actions on the basis of which the archery technique is performed [20-21]. One of the main indicators of technical excellence are efficiency and cost-effectiveness of actions. No less important are the indicators of accuracy and reliability that ensure the sustainability of the sporting result. In turn, the improvement of sports equipment will be fruitful and effective only if it provides for the formation of a biomechanically rational structure of movements, in accordance with the actual level of physical fitness of an athlete. After all, archery in competitive conditions requires the athlete to repeatedly use muscular efforts in static, overcoming and progressive modes and provide stretching of the bow $(15-25 \mathrm{~kg})$, holding the pose at the time of aiming (up to $10 \mathrm{~s}$ ). In this study, the indicators of physical and technical readiness of young archers in the process of learning motor actions are analyzed. The data obtained emphasize the importance of the level of development of static and dynamic strength endurance, coordination of movements in the process of improving the sports and technical skills of athletes at the stage of special basic training. At this stage, to a greater extent than at previous ones, technical improvement is based on various rifle exercises. For example, shooting with different time intervals reached the arrows and the shot as a whole, without visual control, etc. As a result of the work on this and subsequent stages of many years of training, the archer must master the technique of many special preparatory exercises quite well. This approach forms his ability to quickly master the technique of shooting an Classic bow, which corresponds to his morphofunctional capabilities, and further provides the shooter with the ability to vary the basic parameters of technical skill depending on the conditions of specific competitions [2-22]. Thus, during this period, the focus should be on the development of static strength endurance, which provides for a long and repeated repetition of the posture on the alert and maintain it for a certain time, these actions are aimed at adapting the archer's body to specific loads. The optimal distribution of the efforts of all muscle groups involved in the implementation of an aimed shot is largely dependent on the level of development of dynamic strength endurance. Therefore, the development of this quality should be aimed at ensuring coordinated actions of numerous muscle groups of the back, arm, which directly performs the tension of the bow and arm, which provides the content of the bow and counteracts its pressure. The development of coordination abilities lays the foundation for the further development of accurate perception and reproduction of muscular efforts, as well as the ability to differentiate temporal, velocity, and power characteristics in combination of movements provide a shot. Therefore, it is necessary to develop the ability to effectively manage muscle tension and relaxation [22]. The manifestation of power abilities is closely related to the efficiency of the energy supply of the respective work, the level of development of speed abilities and flexibility, they are necessary for keeping the bow and resistance to its pressure, as well as for stretching the bow, so special strength is developed regarding the archer's technical actions.

The results of the study determine the main directions of physical training of archers from the bow of 14-15 years old, specializing in the Classic bow. To optimize the training process of athletes of this age category, optimal tools, forms and methods of training athletes were selected. For the development and improvement of static power endurance, the use of the method of strictly regulated exercises with the use of special schemes, providing for a long bow holding and tight rest intervals, has been proposed. For the development of dynamic strength endurance, it is recommended to perform multiple imitations of bow tension with a resistance of $25-50 \%$ of the maximum force at an average pace until complete fatigue (work on a simulator with the exception of a hand holding a bow, or with a rubber band) $60-70 \%$ of maximum effort at an average pace. Special dexterity should be developed with the help of exercises characteristic of the activity of the archery bow. When training coordination abilities, it should be taken into account that the archer simultaneously performs several technical actions that require coherence in the work of various muscle 
groups (bow holding, resistance to bow pressure, bow tension and orientation in the shooting plane, maintaining the necessary posture, correct brush position, which ensures release of a bowstring), and corrects various characteristics of his movements, agreeing with changes in the situation. In this regard, modeling the complicated conditions of activity in the process of shooting (reducing the time allotted for shooting, changing light, shooting in adverse meteorological conditions, etc.), which cause the archer to change the pace and rhythm of shooting, take into account the influence of artificially introduced obstacles and look for new ways to overcome the difficulties. For the development and improvement of speed capabilities, it is recommended to perform multiple repetitions of speed actions with maximum or maximum intensity on stimulus signals with a gradual reduction in response time without disrupting the execution technique. Exercises related to the imitation of individual elements of a shot with an arrow can be used, or directly shooting at various distances with specific tasks. For the development of strength, exercises with weights, exercises using various training devices and exercises that are performed at a slow pace with significant muscle tension are proposed.

Thus, regular monitoring and accounting of the dynamics of physical and technical readiness, proper selection of means and methods of sports training will optimize the training process of the archers at different stages of many years of training and adjust it when changing any training conditions (changes in the competition calendar, injuries, diseases and etc.).

\section{Conclusions}

It is shown that the indicators of complex testing of archers from 14 to 15 years old, specializing in Classic bow, are divided into five factors: static power endurance, dynamic power endurance, coordination capabilities, speed capabilities, strength capabilities. It was revealed that the first, the most important factor, included shooting indicators in the open air and indicators of the static power endurance of the archer, the second included shooting indicators in the room and indicators of the dynamic power endurance of the archer, which indicates the dependence of physical and technical training in archery. The use of rational means and methods of physical and technical training of archers on the stage of special basic training for the optimal construction of the training process of athletes is recommended.

\section{Acknowledgements}

The study was conducted according to: research work, which is funded by the state budget of the Ministry of Education and Science of Ukraine for 2017-2018. "Theoretical and methodological foundations of the application of integrated technologies for self-improvement, harmonious physical, intellectual and spiritual development and the formation of a healthy lifestyle for people of different age and social groups, including athletes and people with special needs" (State Registration No: 0119U100616).

\section{Conflict of interest}

The authors declare that there is no conflict of interest.

\section{References}

1. Vinogradsky BA. Sports archery: fundamentals and improvements of special preparedness. Monograph: LDUFK;2012.

2. Symanovich PG. Means and methods of integrated control young archers. Pedagogics, psychology, medical-biological problems of physical training and sports. 2005;4:82-88.

3. Antonov SV, Pityn MP. Effectiveness of qualified riflemen archery in control exercises with difficult conditions performance. Pedagogics, psychology, medical-biological problems of physical training and sports. 2011;9:8-10.

4. Artiuh, V, Kozina Z, Koval V, Safronov D, Fomin S, Novikov Y. Influence of application of special means of development of equilibrium and precision-target movements on the level and structure of psychophysiological indicators, physical and technical readiness of archers. Health, Sport, Rehabilitation. 2019;4(4):7-16.

doi:http://dx.doi.org/10.5281/zenodo.2536441.

5. Lankford DE, Higginson B. The effect of fatigue and elevated heart rate on archery shot performance. Medicine and Science in Sports and Exercise. 2016;48(5):858-858. doi:10.1249/01.mss.0000487571.81523.18

6. Lantz K, Webste J, Krueger J. The effects of monocular versus binocular aiming on archery performance. Investigative ophthalmology \& visual science. 2018;59(9):2962-2967.

7. Tarasova LV, Mankhanov ZS. Special performance of highly qualified arrow arrows. Theory and methods of high performance sport. 2014;9:44-46.

8. Korobeinikova EY, Leonov SV, Polikanova IS. Psychological features of attention in archery. National Psychological Journal. 2017;2:35-45. doi: 10.11621/npj.2017.0205. 
9. Ariffin MS, Rambely AS, Ariff NM. Wrist muscle activity of khatrah approach in mameluke technique using traditional bow archery. UniversityKebangsaan-Malaysia, Faculty-of-Science-andTechnology (UKM FST) Postgraduate Colloquium. Univ Kebangsaan Malaysia, Fac Sci \& Technol, Selangor. 2018;1940:12-13.

10. Simsek D, Cerrah AO, Ertan HA. Comparison of the ground reaction forces of archers with different levels of expertise during the arrow shooting. Science \& sports. 2019;34(2):137-145.

11. Taha Z, Musa RM, Majeed PP. The identification of high potential archers based on fitness and motor ability variables: A Support Vector Machine approach. Human movement science. 2018;57:184-193.

12. Shinohara H, Urabe Y. Analysis of muscular activity in archery: a comparison of skill level. Journal of sports medicine and physical fitness. 2018;58(12):1752-1758.

13. Muazu MR, Majeed AP, Abdul T, Zahari T, Siow WC. A machine learning approach of predicting high potential archers by means of physical fitness indicators. S. PLoS ONE. 2019;14(1):e0209638. doi.org/10.1371/journal.pone.0209638

14. Nabavinik M, Abaszadeh A, Mehranmanesh M. Especial skills in experienced archers. Journal of motor behavior. 2018;50(3):249-253.

15. Sobko IN, Ulaeva LA, Yakovenko YA. Factorial structure of physical rehabilitation group students' complex fitness. Physical education of students. 2016;20(2):32-37.

16. Shepelenko T, Kozina Z, Cieślicka M, Prusik K, Muszkieta R, Sobko I, Ryepko O, Bazilyuk T, Polishchuk S, Osiptsov A, Kostiukevych V. Factor structure of aerobics athletes preparation. Pedagogics, psychology, medical-biological problems of physical training and sports. 2017;21(6):345-352.

17. Kozina ZhL, Cieslicka M, Prusik K, Muszkieta R, Sobko IN, Ryepko OA, Bazilyuk TA, Polishchuk SB, Osiptsov AV, Korol SA. Algorithm of athletes' fitness structure individual features' determination with the help of multidimensional analysis (on example of basketball). Physical education of students. 2017;21(5):225-238.

18. Kozina Z, Bazilyuk T, Boyko A. Analysis of the structure of the integrated preparedness of qualified handball players using the methods of multivariate analysis. Health, sport, rehabilitation. 2017;3(2):1524. doi: http: //dx.doi.org/10.34142/zenodo.1109904.

19. Kozina Z, Khrapov S, Yevstratov S, Kolomiets N, Hryshchenko S, Minenok A, Nosko I. Individual factor structure of qualified volleyball players' preparedness. Health, sport, rehabilitation. 2019;5(1):56-65. doi:http://dx.doi.org/10.34142/HSR.2019.05.01.06

20. Baydychenko TV, Arkhipova EA, Shakirov RV. Improving the technical performance of the athletes, classic bow shooters. Scholarly notes. 2014;3(109):1925. DOI: 10.5930/issn.1994-4683.2014.03.109.p19-25

21. Gonzalez CC, Causer J, Grey MJ. Exploring the quiet eye in archery using field- and laboratory-based tasks. Experimental brain research. 2017;235(9):2843-2855

22. Simsek D, Cerrah AO, Ertan H. Muscular coordination of movements associated with arrow release in archery. South african journal for research in sport physical education and recreation. 2018;40(1):141155.

\section{Information about the authors}

\section{Інформація про авторів}

\section{Sobko I.N.}

http://orcid.org/0000-0001-5588-4825

sobko.iryna18@gmail.com

H. S. Skovoroda Kharkiv National Pedagogical University Alchevskikh st. 29, Kharkiv, 61002, Ukraine

\section{Kovtun A.L.}

http://orcid.org/0000-0001-5588-4691

sobko.iryna18@gmail.com

H. S. Skovoroda Kharkiv National Pedagogical University Alchevskikh st. 29, Kharkiv, 61002, Ukraine

\section{Ulaeva L.O.}

http://orcid.org/0000-0003-0468-756X

lorik2340@gmail.com

National University of Pharmacy;

61002, Kharkiv, st. Pushkinskaya, 53, Kharkov, Ukraine

\section{Собко I.М.}

http://orcid.org/0000-0001-5588-4825

sobko.iryna18@gmail.com

Харківський національний педагогічний університет імені Г. С. Сковороди

вул. Алчевських, 29, Харків, 61002, Україна

\section{Ковтун А..Л.}

http://orcid.org/0000-0001-5588-4569

sobko.iryna18@gmail.com

Харківський національний педагогічний університет імені Г. С. Сковороди

вул. Алчевських, 29, Харків, 61002, Україна

Улаєва Л.О.

http://orcid.org/0000-0003-0468-756X

lorik2340@gmail.com

Національний фармацевтичний університет; 61002, м. Харків, вул. Пушкінська, 53, Харків, Україна 